\title{
Magdalena Zamorska
}

ORCID: 0000-0003-3078-1648

Uniwersytet Wrocławski

\section{Etyka roślin. Wiedza, troska i stawanie się z Innymi}

Abstrakt: Autorka domaga się etyki roślin uwrażliwionej na ich Inność. Przedstawia główne stanowiska w obrębie etyki środowiskowej, koncentrując się na postulatach przekroczenia pozycji ekstensjonistycznych; odpowiada na pytania o to, w jaki sposób roślina wyłania się w materialno-dyskursywnych procesach i w jaki sposób zostaje wpisana w reżimy biopolityczne; przedstawia ujęcia rośl-inności uwzględniające specyfikę rośliny jako istoty procesualnej (Houle) i otwartej (Pouteau). Autorka upomina się o etykę roślin pojmowaną jako oparta na wiedzy etyka troski o Innego uwikłanego w wielorakie materialne i ucieleśnione procesy współ-stawania się.

Słowa-klucze: rośliny, etyka, biopolityka, stawanie się, troska

Organizmy roślinne zajmują, według różnych źródeł, od 94 do 99,9\% ziemskiej biomasy. Dyskurs antropoceniczny winą za utratę różnorodności biologicznej obarcza ludzkie działania podporządkowane ekonomicznemu paradygmatowi nieskończonego wzrostu, który przyczynił się i przyczynia do intensyfikacji aktywności rolniczej, ekstraktywistycznej i rozwoju wspierającego ją sektora biotechnologii. W tym kontekście troska o organizmy roślinne wyraża się między innymi przez sprzeciw wobec dalszego rozwoju gospodarki plantacyjnej (obejmującej monokulturowe uprawy, przemysłową hodowlę zwierząt oraz intensywną gospodarkę leśną), a także postulowanie społecznej kontroli nad manipulacjami w obrębie kodu genetycznego i praktykami patentowania organizmów żywych. Postulaty etycznego działania dotyczą więc praktyk bio- i nekropolitycznych w odniesieniu do roślinnych zbiorowisk, botanicznych gatunków oraz kodu genetycznego organizmów wegetalnych.

Intensywnie rozwijające się w ostatniej dekadzie nauki biologiczne oraz humanistyczne studia nad roślinami (i szerzej — życiem) radykalnie przekształcają ludzki sposób postrzegania istot wegetalnych ${ }^{1}$. W ostatnim dziesięcioleciu biologia roślin dokonała wielu przełomowych dla nauki odkryć związanych z zacho-

\footnotetext{
${ }^{1}$ Literaturę pokrótce omówiłam we wstępie do tego numeru.
} 
waniami i percepcją roślin oraz ich sposobami komunikowania się i tworzenia splotów wielogatunkowych, które wydają się potwierdzać intuicje na temat rzeczywistości roślinnych, formułowane w obrębie nieeuropejskich i przednowożytnych epistemologii i kosmologii. Reprezentantki i reprezentanci wielu dyscyplin humanistyki interesują się już nie tylko specyfiką praktyk kulturowych związanych z roślinami oraz relacjami roślin i ludzi, ale też poddają namysłowi procesy roślinnego światotworzenia oraz wyłaniania się sieci i splotów między- i postgatunkowych, wielogatunkową i wieloczynnikową transkorporealność oraz procesy koewolucyjne, sympojetyczne, których uczestnikami są organizmy wegetalne.

Etyka roślin, o którą się upominam — i która ostatecznie zawsze już jest etyką „naczyń połączonych" - z jednej strony uznaje konieczność rozstrzygnięć dotyczących wskazanych problemów, z drugiej zaś - domaga się faktycznego wzięcia pod uwagę interesów (potrzeb, pragnień) roślin, czyli żywych istot w nieustającym procesie morfogenezy, wytwarzających światy w relacji z wieloma innymi, równie dynamicznie przekształcającymi się formami życia.

W pierwszej części artykułu (Wartość roślin) przedstawię — w bardzo dużym skrócie - dominujące stanowiska w obrębie etyki środowiskowej, ponieważ to $\mathrm{w}$ tym polu dyscyplinarnym podjęto próbę systematycznego podsumowania postulatów etycznych sformułowanych w odniesieniu do roślin. Ze względu na dalsze rozważania koncentruję się na postulatach przekroczenia pozycji ekstensjonistycznych. W drugiej części (Rośl-inność ${ }^{2}$ ) spróbuję odpowiedzieć na — wydawać by się mogło - banalne pytanie, co mamy na myśli, gdy myślimy o roślinie. Filozofia roślin została wpisana w reżimy bio- i nekropolityczne dyskursywno-materialne praktyki uczyniły z rośliny modelowego Innego nowożytnej kosmologii (Nealon). Równocześnie świat pojęciowy został ukształtowany przez wyobrażenia zwierzęco-kształtne. Podstawowym więc problemem, który uniemożliwia realną transgresję pozycji ekstensjonistycznych, jest przyjmowana bezrefleksyjnie zoo- i antropomorficzna ontologia i epistemologia istoty roślinnej.

Etyka roślin wymaga od nas uważności na wielość form życiowych, rozmaitość procesów stawania się w świecie roślinnym. W rozważaniach dotyczących stawania-się-życia istoty roślinne często „znikają” pośród innych agensów, wymieniane jednym tchem z kamieniami, wodą, wiatrem, drobnoustrojami itp. Konieczna jest głębsza refleksja nad samą zasadą rośl-inności (plantness), czyli odrębnością i specyfiką istoty wegetalnej, istoty otwartej, którą podejmują między innymi Karen Houle i Sylvie Pouteau. To niezwykle bliskie mi podejście przedstawię w części trzeciej (Morfogeneza istoty otwartej).

W ostatniej części (Relacyjność, troska i wiedza) wskażę możliwość i konieczność poddania istot roślinnych refleksji w polu etyki stawania-się-z (Haraway, Barad), etyki troski (Puig de la Bellacasa, van Dooren) i etyki podatności na zra-

2 Termin „rośl-inność”, który uważam za niezwykle trafny, zapożyczyłam z tytułu pisma „Czas Kultury" 146, 2008, nr 5. 
nienie (Hird). Podejścia te biorą pod uwagę złożoność transkorporealnych (Alaimo) rzeczywistości. Dla teorii i praktyki etycznej, która rozstrzyga — również na żywym ciele, in vivo i in vitro - dylematy i konflikty relacji roślinno-ludzkiej, konieczne jest ujęcie życia w perspektywie filozofii procesu i stawania się (Deleuze, Guattari).

\section{Wartość rośliny}

Michael Marder, autor fundamentalnej dla krytycznych filozoficznych studiów nad roślinami książki Plant-Thinking ${ }^{3}$, w eseju Plant morality vs plant ethics ${ }^{4}$ zwraca uwagę na konieczność podjęcia rozważań dotyczących życia roślinnego w polu etyki, a nie moralności. Filozof definiuje moralność jako preskryptywny system normatywny opierający się na zasadach i regułach określających, czym jest właściwe postępowanie; z kolei etyka w jego ujęciu jest „sposobem życia, sposobem egzystencji”, scenariuszem działań i wyborów tworzonym w czasie rzeczywistym, spotkaniem, „egzystencjalnym skrzyżowaniem”. Moralność zakłada dystans pomiędzy bytami, osobność poszczególnych uczestników relacji i możliwość apriorycznego ważenia ich jednostkowych interesów, natomiast etyka wychodzi od konstatacji, że różne byty zawsze już są w relacji, współtworzą i współdzielą światy, a zatem gest normatywizacji zawsze już jest spóźniony.

Oczywiście moralność i etyka nie zawsze są rozgraniczane w taki sposób, jak czyni to Marder, co więcej - postulaty etyczne są formułowane w obrębie wielu dyscyplin humanistyki (studiów kulturowych, etnologii, socjologii) oraz w obszarze studiów transdyscyplinarnych. Zdecydowałam się na używanie - w tej części artykułu - poszczególnych kategorii, podążając za autorkami oraz autorami, których koncepcje i postulaty referuję bądź interpretuję, w związku z czym pojawią się takie sformułowania, jak chociażby „etyka środowiskowa jako subdyscyplina filozofii moralnej”, które w kontekście dotychczasowych rozważań mogą wydać się wewnętrznie sprzeczne. W tym bardzo skrótowym przeglądzie pozycji i postulatów przyjmowanych w obrębie etyki środowiskowej przyjrzę się przede wszystkim podejściom, ujęciom i stanowiskom formułowanym w ramach projektu „New Directions in Plant Ethics” realizowanego pod kierunkiem Angeli Kallhoff na Wydziale Filozofii Uniwersytetu Wiedeńskiego w latach 2014-2019. Skoncentruję się na moim zdaniem niezwykle istotnym geście krytyki propozycji ekstensjonistycznych.

\footnotetext{
${ }^{3}$ Por. M. Marder, Plant-Thinking: A Philosophy of Vegetal Life, New York 2013.

${ }^{4}$ M. Marder, Plant morality vs plant ethics, 2016, https://philosoplant.lareviewofbooks.org/?p=177 (dostęp: 29.01.2020).

5 Ibidem.
} 
Dyskusja dotycząca możliwości rozważania statusu roślin w obrębie filozofii moralnej rozgorzała $\mathrm{w}$ trakcie debat poprzedzających zamieszczenie przepisu o ochronie godności żywych istot, bezpieczeństwie człowieka, zwierząt i środowiska oraz genetycznej różnorodności w konstytucji Szwajcarii z 1999 roku (art. 120 $\S 2$ ). Wielu teoretyków zwróciło uwagę, że sformułowanie zawarte w tym dokumencie odzwierciedla różne i często rywalizujące bądź sprzeczne z sobą poglądy na kwestie szacunku wobec środowiska i nie-ludzi, łącząc podejścia antropocentryczne, holistyczne (biocentryczne, ekocentryczne), związane z ochroną praw zwierząt oraz dobrostanem (welfare) istot żywych ${ }^{6}$. W 2008 roku Federalny Etyczny Komitet ds. Bioechnologii Nie-ludzi (ECNH) wydał uzupełniające oświadczenie zatytułowane „Godność (Würde, dignity) żywych istot w odniesieniu do roślin”7. Status roślin w dyskursie publicznym zmieniał się jednak już od lat osiemdziesiątych. Sabine Odparlik wskazuje, że na zmianę tę mogły wpłynąć: rosnąca popularność zagadnień związanych z kryzysem środowiskowym w publicznym dyskursie oraz popularność ruchów ekologicznych; wpływ środowiskowego dyskursu anglojęzycznego włączającego rośliny, reprezentowanego przez Robina Attfielda i Paula W. Taylora; pojawienie się nowej dyscypliny, początkowo zwanej neurobiologią roślin; rozwój biotechnologii, która poprzez umożliwienie tworzenia transgatunkowych hybryd skierowała uwagę na wspólne pochodzenie roślin i zwierząt; w końcu rozpowszechnienie się idei integralności żywych stworzeń, która może zostać pogwałcona ze szkodą dla danego organizmu ${ }^{8}$.

Filozofia moralna pyta o wartość roślin. Z perspektywy subiektywnej aksjologii roślin źródłem wartości są oceniający (valuers), natomiast z perspektywy obiektywnej — wartość roślin jest niezależna od osądu, nieinstrumentalna, ostateczna i dana ze względu na nie same (for their own sake), rośliny mają wartość inherentną, wrodzoną (intrinsic) ${ }^{9}$. Reprezentantki i reprezentanci etyki środowiskowej — rozwijanej w obrębie filozofii moralnej — uznają bądź instrumentalną (podejścia antropocentryczne lub rzadziej zoocentryczne), bądź inherentną wartość rośliny (podejścia „silnie biocentryczne” — za Attfieldem ${ }^{10}$ ).

Zgodnie z pierwszym, instrumentalnym, podejściem roślina ma wartość ze względu na fakt świadczenia tak zwanych usług ekosystemowych (dostarczanie piękna krajobrazowego, produkcja tlenu, pokarmu itp.), których beneficjentem jest człowiek (podejścia antropocentryczne) lub rzadziej inne zwierzę (czyli inna odczuwająca istota mająca status moralny) — takie ujęcie najczęściej pojawia

${ }^{6}$ S. Odparlik, The dignity of plants. An overview of the discussion in German-speaking countries, [w:] Plant Ethics: Concepts and Applications, red. A. Kallhoff, M. Di Paola, M. Schörgenhumer, Abingdon-Oxon-New York 2018, s. 59-69.

${ }^{7}$ ECNH, The Dignity of Living Beings with Regard to Plants: Moral Consideration of Plants for Their Own Sake, Berne 2008.

${ }^{8}$ Ibidem, s. 61-62.

${ }^{9}$ G. Pellegrino, The value of plants. On the axiologies of plants, [w:] Plant Ethics..., s. 14-15.

10 Por. R. Attfield, Forest ethics, [w:] Plant Ethics..., s. 121-130. 
się w kontekście rozważań dotyczących rolnictwa, konserwacji biologicznej, biorobotyki. W tym ujęciu regulacje co do sposobu traktowania roślin związane są z powiększaniem dobrostanu nie samych roślin, lecz ludzi (perspektywa antropocentryczna), ludzi i zwierząt (perspektywa zoo- lub patocentryczna, czyli obejmująca istoty odczuwające i zdolne do cierpienia) bądź ekosystemu, które te istoty współtworzą lub w którym żyją (perspektywa ekocentryczna).

W drugim podejściu rośliny mają wrodzoną wartość, niezależną od ich znaczenia dla ludzi, zwierząt i ekosystemów. W ujęciach nieantropocentrycznych uznaje się inherentną wartość roślin ze względu na określone definicyjnie cechy bytu roślinnego - roślina ma wartość jako żywa istota w ujęciu biocentrycznym (Taylor, Attfield), efekt procesów naturalnych w ujęciu naturocentrycznym, a nawet system nakierowany na osiągnięcie celu w ujęciu teleologicznym ${ }^{11}$.

Reprezentanci i reprezentantki podejść ekstensjonistycznych, odpowiadając na pytanie, którym istotom należny jest osąd moralny, wykorzystują kategorie etyczne wypracowane wcześniej w obrębie etyki (ludzkiej). W przypadku utylitaryzmu są to kategorie interesu, przyjemności i bólu, w etyce kantowskiej rozumu i godności, a arystotelesowskiej — cnoty i szczęścia ${ }^{12}$. Ekstensjonizm uwzględnia inherentną wartość roślin, co w konsekwencji prowadzi do przyznania bytom wegetalnym statusu moralnego oraz stosownych praw. Roślina zyskuje status moralny, ponieważ zostaje uznana za istotę odczuwającą, wrażliwą (ekstensja patocentryczna w ramach ujęć zoocentrycznych), autonomiczną, kierującą się własnym interesem lub dobrem (ekstensja zoomorficzna) czy nawet mającą własną godność i inteligencję (ekstensja antropomorficzna).

Etyka środowiskowa rodzi wiele zastrzeżeń wysuwanych z różnych pozycji. Po pierwsze, o czym pisze Gianfranco Pellegrino, etyka środowiskowa zwykle postrzega rośliny jedynie jako element większej całości (życia, przyrody, ekosystemu, zbiorowości, środowiska), co prowadzi do dość swobodnego tworzenia analogii funkcjonalnych pomiędzy roślinnym, zwierzęcym, ludzkim ${ }^{13}$. W tym kontekście Tatjana Višak wskazuje powszechną tendencję do utożsamiania cech i funkcji życia roślinnego, takich jak poruszanie się, odczuwanie, komunikacja, altruizm, z cechami i funkcjami organizmu ludzkiego, słusznie wyjaśniając, że każda z tych funkcji czy zachowań służy u roślin czemuś innemu niż u człowie$\mathrm{ka}^{14}$. Po drugie, traktowanie roślin jako elementu większej całości zwalnia teoretyków z konieczności ustosunkowania się do bytu roślinnego jako organizmu wymagającego osobnego namysłu etycznego, biorącego pod uwagę specyficzne cechy życia roślinnego i nieignorującego poszczególnych istnień roślinnych ${ }^{15}$.

11 Por. R. Sandler, Is considering the interests of plants absurd?, [w:] Plant Ethics..., s. 40-50.

12 A. Kallhoff, Plants in ethics: Why flourishing deserves moral respect, „Environmental Values" 23, 2014, nr 6, s. 690.

13 Por. G. Pellegrino, op. cit.

14 T. Višak, Utylitarian plant ethics, [w:] Plant Ethics..., s. 31-32.

15 G. Pellegrino, op. cit., s. 15-21. 
U źródeł tego „przeoczenia” leży niechęć wielu teoretyków etyki środowiskowej do najnowszych ustaleń nauk biologicznych badających zachowanie, percepcję czy komunikację roślin, zgodnie z którymi rośliny są uznawane za organizmy aktywne, sprawcze, autonomiczne, postrzegające i czujące, zdolne do komunikacji i złożonych zachowań adaptacyjnych, a także pamiętające, uczące się, a nawet inteligentne ${ }^{16}$. Višak jako przykład podaje powszechne założenie wykluczające rośliny z namysłu utylitarystycznego (skupionego na dążeniu przez daną istotę do własnego dobrostanu) - jako że rośliny nie mają systemu nerwowego, nie odczuwają bólu (zakłada się, że ponieważ ból jest katalizatorem reakcji ucieczki, byłby bezużyteczny w wypadku istoty niemobilnej), a także nie mają preferencji ani upodobań będących źródłem działań intencjonalnych i świadomych (tu z kolei sprawczość zostaje antropomorficznie utożsamiona z możliwością przypisania działaniu znaczenia $)^{17}$.

Założenie, że „zgodnie z aktualną wiedzą rośliny nie są istotami czującymi, a także są pozbawione samoświadomości oraz świadomej sprawczości" ${ }^{18}$, przyjął również zespół realizujący projekt „New Directions in Plant Ethics”. W konsekwencji uznano, że strategie, które wcześniej umożliwiły moralny namysł nad zwierzętami, nie sprawdzą się w przypadku roślin. W projekcie realizowanym przez zespół pod kierunkiem Kallhoff skupiono się na moralnym wymiarze kulturowych praktyk związanych z roślinami. Wyodrębniono trzy nieekstensjonistyczne podejścia, które pozwalają wziąć pod uwagę radykalną odmienność roślin ${ }^{19}$. Pierwsze dwa wiążą wartość rośliny i jej status moralny z jej znaczeniem dla życia i dobra istot czujących (omówione już podejście instrumentalne). Pierwsze podejście, nazywane tu „nie-moralnym podejściem inkluzywnym”, włącza rośliny w obręb namysłu moralnego, ale nie przyznaje im statusu moralnego. Życie roślin jest ważne dla odczuwających istot (czyli zwierząt ludzkich i nie-ludzkich) i tylko z tego względu ma wartość oraz zasługuje na szacunek. Reprezentanci tego podejścia często posługują się językiem sprawiedliwości, deklarując i postulując ludzkie zobowiązania dotyczące konieczności ochrony oraz zachowania gatunków, populacji oraz bioróżnorodności. Drugim wyodrębnionym podejściem jest „podejście relacyjne”, zgodnie z którym wartość oraz moralne znaczenie roślin są konsekwencją ich uwikłania w ludzkie praktyki, zwłaszcza te związane z ich nieprzemysłowymi formami uprawy i zbieractwa (ogrody, mikrouprawy permakulturowe, rośliny domowe, dzikie rośliny jadalne). Miejsce języka zobowiązania i sprawiedliwości zajmuje tu język troski i cnoty oraz poszukiwania normatywnych kryteriów przydatnych w praktykach hodowli roślin. Trzecie, szczególnie mnie interesujące, podejście uznaje „samoistną wartość” (value-in-nature) roślin.

${ }^{16}$ Na początek warto sięgnąć po prace takich badaczy i badaczek, jak František Baluška, Daniel Chamovitz, Monica Gagliano, Stefano Mancuso czy Anthony Trewavas.

17 T. Višak, op. cit., s. 31-33.

18 A. Kallhoff, M. Di Paola, M. Schörgenhumer, Introduction, [w:] Plant Ethics..., s. 1.

${ }^{19}$ Ibidem, s. 2-3. 
Reprezentantki tego stanowiska nie powołują się jednak na klasyczne kategorie wrodzonej lub inherentnej wartości roślin — te kategorie są związane raczej z dociekaniami w obrębie strategii ekstensjonistycznych - lecz rozważają, co może stanowić wartość d la sa mej rośliny. Postulują poznanie specyfiki procesów życiowych rośliny, odejście od indywidualistycznej ontologii bytów (związanej z proliferacją takich kategorii jak autonomia, integralność czy godność jednostki) i skupienie się na kategoriach charakterystycznych dla bytów roślinnych, takich jak pełnia rozwoju ${ }^{20}$ (flourishing) i otwartość (openness).

W obrębie trzeciego ujęcia Angela Kallhoff podważa ekstensjonistyczną linię wnioskowania, wskazując, że postulat konieczności zapewnienia warunków dla pełni rozwoju dotyczy wszystkich żywych istot, jednak nie służy zrównaniu ich z sobą, lecz wskazaniu specyfiki ich procesu rozwoju. Filozofka powołuje się na twierdzenia Arystotelesa, dokonując reinterpretacji jego analiz dotyczących aktywności „duszy roślinnej” w procesach odżywiania, wzrostu i rozmnażania. Roślina „rozwija się w czasie poprzez transformację energii i substancji chemicznych w nowe materiały" ${ }^{21}$. Jak każda żywa istota aktywnie dąży do osiągnięcia pełni rozwoju, wybierając i modyfikując określone strategie. Rośliny są bytami autonomicznymi, aktywnie zarządzającymi własnym życiem, dbającymi o własną integralność, właściwe funkcjonowanie i rozwój. W przypadku roślin naczyniowych (których procesy życiowe analizuje Kallhoff ${ }^{22}$ ) pełnia rozwoju wymaga spełnienia trzech warunków: (1) możliwości reagowania na stres środowiskowy bez narażania własnej żywotności, (2) możliwości spełnienia cyklu życiowego, (3) możliwości ekspresji cech typowych dla swojego gatunku ${ }^{23}$. Uniemożliwienie realizacji któregokolwiek z nich jest etycznie niewłaściwe, ponieważ szkodzi roślinie.

Rośl-inność

Mimo otwartej krytyki ujęć ekstensjonistycznych propozycja Kallhoff ma, moim zdaniem, podstawową słabość — uznaje metafizyczny indywidualizm za

20 Zdecydowałam się tłumaczyć kategorię flourishing jako ,pełnię rozwoju”, ponieważ słowo „rozwój” nie oddaje kluczowej tu teleologii dopełnienia, a wyraz „kwitnienie”, choć funkcjonuje w języku polskim również jako metafora (na przykład „wyglądasz kwitnąco”), równocześnie odsyła do konkretnego procesu wytwarzania kwiatów, tym samym gubiąc szersze znaczenie - szeroko rozumianego rozwoju również w innych aspektach cyklu rozwojowego rośliny (i nie tylko).

${ }^{21}$ A. Kallhoff, The flourishing of plants: A neo-Aristotelian approach to plant ethics, [w:] Plant Ethics..., s. 53. O ile nie podano inaczej, cytaty w przekładzie autorki.

${ }^{22}$ Oczywiście problematyczny jest zarówno arbitralny wybór roślin naczyniowych — rośliny naczyniowe najłatwiej też poddają się analogizacji, zoo- i antropomorfizacji — jak i użycie kategorii gatunku, która nie jest w biologii kategorią ontologiczną, ale epistemologiczną, czyli pewnym uproszczeniem poczynionym na rzecz przejrzystości systematycznej w obrębie taksonomii.

${ }^{23}$ A. Kallhoff, Plants in ethics..., s. 688. 
właściwy punkt wyjścia projektu etyki roślin, czyli nie poddaje namysłowi samego procesu transkrypcji antropo- i zoomorficznego wyobrażenia istoty zamkniętej, niepodzielnej i skończonej na istotę roślinną. Špela Petrič, słoweńska badaczka i artystka pracująca z organizmami roślinnymi, zwraca uwagę na jeszcze inny, głębszy, problem — konieczność udzielania każdorazowo odpowiedzi na pytanie o samo pojęcie rośliny.

W rzeczywistości słowo „roślina” łączy organizmy tak różne, jak jednokomórkowa alga, trawa cytrynowa i brzoza; te rośliny mają z sobą niewiele wspólnego poza podobnym planem komórkowym (czymś analogicznym byłaby próba sprowadzania człowieka i nicienia do wspólnego mianownika). Myślenie o „roślinie” jest formą rasizmu, niesprawiedliwą generalizacją lekceważącą konkretną istotę ${ }^{24}$.

Ponieważ w królestwie roślin znajdziemy organizmy jedno- i wielokomórkowe, ukorzenione i nieukorzenione, wytwarzające tkankę przewodzącą wodę (naczyniowe) i jej niewytwarzające, produkujące nasiona i pyłek (nasienne) oraz ich nieprodukujące, kwitnące i niekwitnące, jak również pozbawione chlorofilu i nieprzeprowadzające procesu fotosyntezy (!), Petrič domaga się uwrażliwienia na czasowe i lokalne formy ekspresji życia roślinnego, na niepowtarzalne u-materialnienia i u-cieleśnienia istoty roślinnej.

Nie tylko życie roślinne jest problematyczne — również śmierć rośliny jest dyskursywnie ramowana na wiele sposobów. Zwraca na to uwagę australijski badacz John Ryan, wskazując trzy sposoby definiowania śmierci roślinnej: „koniec życia pojedynczego organizmu roślinnego, odejście florystycznego zbiorowiska lub, bardziej dalekosiężne, wymarcie botanicznego gatunku, genetycznej matrycy umożliwiającej powstawanie roślin" ${ }^{25}$. Ryan rozpoznaje dwa rodzaje śmierci roślinnej: antropogeniczną i biogeniczną ${ }^{26}$. Dyskurs wymierania ekosystemów, zbiorowisk roślinnych i gatunków wiąże się z zagadnieniem śmierci antropogenicznej i w naturalny sposób ewokuje postulat etyki roślin nakierowanej na ochronę tak pojmowanego życia roślinnego. Należy jednak pamiętać również o biogenicznej śmierci rośliny, mniej spektakularnej formie odchodzenia organizmu roślinnego, która także skutkuje „umieraniem świata” — roślina, jak każdy żywy organizm wyłaniający się z materii i materię wytwarzający, „ma swój świat” — wielokształtny, relacyjny, stale kształtujący się w procesie koewolucji.

Etyka roślin wymaga zatem wzięcia pod uwagę lokalnych ekspresji istoty wegetalnej, zarówno w perspektywie jej życia, jak i umierania. Petrič podkreśla specyfikę organizmu roślinnego jako takiego — etyka roślin nie może być

24 Š. Petrič, Confronting Vegetal Otherness: Strange Encounters, https://www.spelapetric.org/ strange-encounters/ (dostęp: 23.06.2020).

25 J.Ch. Ryan, On the death of plants: John Kinsella's radical pastoralism and the weight of botanical melancholia, „Ecozona” 7, 2016, nr 2, s. 114.

${ }^{26}$ Ibidem, s. 113. 
zmodyfikowaną na zasadzie kopiuj-wklej etyką ludzi i zwierząt. Konieczne jest głębsze zrozumienie zasad roślinnych (plant principles), mogące wpłynąć na filozoficzne ujęcia życia roślinnego i stworzyć podstawę nowej metafizyki oraz ontologii roślin, a te z kolei mogą służyć jako punkt wyjścia etyki [roślin] $]^{27}$.

Tę myśl rozwija Jeffrey Nealon, autor pracy poświęconej teorii roślin, proponując radykalizację myśli biopolitycznej przez włączenie życia roślinnego w obręb biopolitycznych rozważań ${ }^{28}$. Ten gest pozwala mu pytać o to, „co uznaje się, a co nie, za organizm zdolny do życia (viable form of life)”, który „zasługuje na polityczne rozpoznanie i ochronę" 29 . Równocześnie dowodzi, że w erze biopolitycznej to życie roślinne, a nie ludzko-zwierzęce występuje w roli abiektalnego Innego ${ }^{30}$, mimo że wyobrażenie we getalnej $\mathrm{zas}$ ady $\dot{z} \mathrm{yc} i$ a (vegetable psukhe of life) „dużo lepiej charakteryzuje naszą biopolityczną teraźniejszość niż ludzko-zwierzęce wyobrażenie życia związane z organizmem, indywidualną istotą z całym jej ukrytym życiem i projektowanym światem"31. Roślinę — biorąc pod uwagę zarówno modularność jej budowy, jak i poszerzony modus jej istnienia, chociażby w postaci kolonii klonalnych - trudno traktować jako indywiduum, czyli dosłownie byt niepodzielny (i oddzielony). Nealon nie próbuje jednak rozpychać kategorii wyemancypowanych podmiotów biopolityki, ale proponuje powrót do zasady życiowej, do pytań o terytorium życia i to, jak życie działa, „W jaki sposób splot (mesh) życia zostaje przekształcony przez taką czy inną praktykę"32.

Rozważania Karen Houle oraz Sylvie Pouteau są szczególnie inspirującym źródłem możliwości myślenia istnienia roślinnego jako z jednej strony specyficznej i niepowtarzalnej formy ucieleśnienia, a z drugiej - matrycy nowej teorii biopolitycznej biorącej pod uwagę roślinne formy życia. Houle, która studiowała biologię, historię i filozofię nauki oraz filozofię polityczną, angażuje się obecnie w prace Guelph Centre for Urban Organic Farming (Ontario, Kanada), gdzie realizuje eksperymentalny projekt pragmatycznej dydaktyki w zakresie etyki środowiskowej i etyki roślin, dla której punktem wyjścia jest praktyka ogrodnicza studentek i studentów. Pouteau zaś zajmuje się badaniem plastyczności roślin w odpowiedzi na zmiany środowiskowe w Institut Jean-Pierre Bourgin (stanowiącym część Institut National de la Recherche Agronomique w Wersalu we Francji), równocześnie rozwijając transdyscyplinarne rozważania w obrębie filozofii nauk biologicznych oraz etyki środowiskowej i etyki roślin.

\footnotetext{
27 Š. Petrič, op. cit.

28 J.T. Nealon, Plant Theory: Biopower and Vegetable Life, Stanford, CA 2016, s. 112.

${ }^{29}$ Ibidem, s. 110.

30 Ibidem, s. 11.

${ }^{31}$ Ibidem, s. 106.

32 Ibidem, s. 114.
} 
Obie filozofki wypracowują swoje propozycje ontologii i etyki roślin, opierając się na filozofii stawania się, a ich twierdzenia i postulaty są $\mathrm{w}$ wielu punktach zbieżne. Houle i Pouteau (1) wskazują etykę zwierząt jako niewłaściwy punkt wyjścia etyki roślin i problematyzują zoomorficzność (zwierzęco-kształtność) etycznego aparatu myślowego, (2) postulują odejście od charakterystycznego dla filozofii zachodniej myślenia obiektowego (ontologii bytów) na rzecz myślenia procesualnego (bycia, stawania się, morfogenezy) oraz (3) wskazują cechy wyjątkowe dla roślinnego stawania się. Filozofki próbują zrealizować dwa z pozoru sprzeczne cele: podważyć sens klarownych ontologicznych cięć oddzielających rośliny od zwierząt i materię ożywioną od nieożywionej oraz nakreślić specyfikę procesu stawania się istotą roślinną.

Pouteau śledzi różne formy narratywizacji kategorii rośliny i zwierzęcia w filozofii oraz nowożytnej nauce, wskazując fluktuację ujęć dychotomizujących i analogizujących te dwa „królestwa”, a następnie ich unifikację w obrębie nowożytnej biologii - w XVIII wieku dostrzeżono podobieństwo (jedność) materii organicznej, z której stworzone są rośliny i zwierzęta, w pierwszej połowie XIX wieku upowszechniła się unifikująca oba królestwa teoria komórkowa, a w początkach XX - teoria genowa. Mimo intensywnego rozwoju botaniki jako subdyscypliny biologii oraz pojmowania biologii jako nauki o życiu ${ }^{33}$ organizm zwierzęcy pozostał, jej zdaniem, modelowym obiektem poznawczym: „zwierzę jest formą, poprzez którą rośliny stają się przedmiotem nauki”34. Roślina jest „drugim zwierzęciem" 35 , jest animalizowana i antropomorfizowana.

Filozoficzny dyskurs zwierzęcia pojawiał się, by wspomóc ontostabilizację człowieka poprzez osadzenie zwierzęcia w roli „nie-człowieka”, czyli Innego ${ }^{36}$. Maszyna etyczna pracuje przez dokonywanie ontologicznych cięć - Houle pokazuje, że moralny status określonych istot może zostać uznany tylko pod warunkiem zastąpienia Innego przez kolejnych Innych-Innego. Wtóruje jej Pouteau, stwierdzając, że ostatnie z cięć ontologicznych ostatecznie ulokowało rośliny po stronie ,rzeczy"37. Rozwijająca się biologia zbadała zdolności adaptacyjne zwierzęcia, kontynuuje Houle, co stało się podstawą uznania zwierzęcych interesów, określenia, czym może być zwierzęce dobro, jak również zwierzęca wrażliwość i cierpienie. W ten sposób zwierzę zostało wyniesione na pozycję podmiotu mo-

${ }^{33}$ Biologia jest rozumiana jako nauka o życiu jako o zasadzie; zoologii (zoon — zwierzę) i biologii (bios — życie konkretnego organizmu) towarzyszy nienazwana zoelogia (zoe — ruch życia, siła życia); por. S. Pouteau, Plants as open beings: From aesthetics to plant-human ethics, [w:] Plant Ethics..., s. 82-97.

${ }^{34}$ Ibidem, s. 83.

35 Por. ibidem; oraz S. Pouteau, Beyond “second animals”: Making sense of plant ethics, ,Journal of Agricultural and Environmental Ethics" 27, 2014, nr 1, s. 1-25.

${ }^{36}$ K. Houle, Animal, vegetable, mineral: Ethics as extension or becoming? The case of becoming-plant, „Journal for Critical Animal Studies” 9, 2011, nr 1-2, s. 93.

${ }^{37}$ S. Pouteau, Beyond..., s. 7-8. 
ralnego w wyniku obsadzenia „niewrażliwej”, czyli niemającej układu nerwowego, rośliny w roli nowego Innego. W tej serii cięć (człowiek — zwierzę - roślina - ...) na pozycji Innych-Innego mogą zostać umieszczone pierwotniaki, inne mikroorganizmy czy nawet minerały.

Houle zwraca uwagę, że same koncepcje są „ciałem myśli”, dlatego, jak każde ciało, przechodzą proces morfogenezy, są przedmiotem presji ewolucyjnej i w miarę upływu czasu tworzą , stabilny, uwzorowany byt-myśli" ${ }^{38}$. Ludzkie ucieleśnienie (enfleshment) ma określoną biofizyczną formę; ludzka „część myślowa” jest uwzorowana, uformowana oraz ukonstytuowana przez działania wynikające z naszego ucieleśnienia. Koncepcje wyłaniają się z naszych zoomorfologicznych wzorców rozwojowych — wertykalności, symetrii, grzbietobrzuszności, linearności, odśrodkowo-dośrodkowości — które prowadzą do patologicznego uwikłania w ,hierarchiczne, dualistyczne, bilateralne, oparte na opozycjach i osądach formy etyki" ${ }^{39}$. Idee etyczne pojawiają się w tak ukształtowanym ludzkim-zwierzęcym ciele, działają i zachowują się jak ciała zwierzęce, dlatego są bezużyteczne w odniesieniu do roślin ${ }^{40}$. Uruchamiając zwierzęco-kształtne (animalesque) koncepcje, pozbawiamy myśl możliwości mutacji i stawania-się-Innym ${ }^{41}$. Pouteau uzupełnia rozważania Houle, pisząc, że geometria euklidesowa (będąca naszym podstawowym narzędziem myślenia i poznawania) zasadza się na pojęciach opartych na morfologii zwierzęcej (pojęciach zoomorficznych) i jest uwzorowana według osi wertykalnej, horyzontalnej oraz sagitalnej. Myślenie i obrazowanie spacjalizacji nie-zwierzęcej (tu: roślinnej) wymaga oparcia się na geometrii nie-euklidesowej42. Filozofka, podobnie jak wcześniej cytowany Nealon, sugeruje powrót do samego pojęcia „życia”, organicznego życia rozumianego jako współdzielony proces ewolucyjny „stawania-się-innym”43. Odejście od koncepcji życia opartej na morfologii zwierzęcej — „rośliny i populacje mikroorganizmów mnożą się nieprzerwanie i nie mają, jak zwierzęta, Newtonowskich granic"44 — na rzecz koncepcji bio- lub raczej zoecentrycznych pozbawiłoby zwierzęta uprzywilejowanej pozycji wzorca morfologicznego w dyskursie biologicznym.

Proces animalizacji i ,zamykania” istoty roślinnej ma miejsce nie tylko na polu dyskursywnym, ale też w popularnych praktykach, których celem jest oswajanie roślin. Pouteau ujmuje relacje roślinno-zwierzęce jako relacje form (ciał) w działaniu, rozgrywające się w polu energii (energeia). Prymarna energia dociera do biosfery $\mathrm{w}$ postaci fotonów (słońce) i zostaje włączona w bioobieg za sprawą

${ }^{38}$ K. Houle, Facing only outwards? Plant bodily morphogenesis and ethical conceptual genesis, [w:] Plant Ethics..., s. 72.

\footnotetext{
39 Ibidem, s. 73-75.

40 Por. ibidem.

${ }^{41}$ Ibidem, s. 72.

42 S. Pouteau, Plants..., s. 85.

43 S. Pouteau, Beyond..., s. 15.

${ }^{44}$ Ibidem, s. 6.
} 
fotosyntezy. Istoty zamknięte (zwierzęta) są metabolicznymi pasożytami istot otwartych (roślin). Istoty wytwarzające wnętrze i zewnętrze (zwierzęta) potrzebują ruchliwości, aby uzewnętrznić własne wnętrze (ja) i napotkać własne zewnętrze (nie-ja); ruchliwość to ich podstawowy sposób wyrazu. Udomowienie roślin przez ludzkość służy „kontroli energii słonecznej i wprowadza radykalne zmiany w metabolizmie Ziemi" ${ }^{45}$. Zasada „dawania owocu” (fructification) dominuje w procesie udomawiania roślin i opiera się na modyfikacji roślinnych form w działaniu przez (ulegające transformacji) ludzkie formy w działaniu. Pola sił formacyjnych istot otwartych i zamkniętych zostają „,ciasno splecione”. Udomowienie roślin można postrzegać jako proces animalizacji roślin, ich zamykania, przez faworyzowanie rozwoju nakierowanego na to-co-zwierzęce ${ }^{46}$. W efekcie udomowienia rośliny (anaboliczne istoty otwarte) zamieszkują trójwymiarową przestrzeń człowieka (katabolicznej istoty zamkniętej), a ich ciągły proces stawania się jest przez nią modelowany. Podobnie jak ludzie rośliny uprawiane przemysłowo otrzymują pokarm z ludzkiej fabryki (syntetyczne nawozy azotanowe), stają się bez-ziemne (soil-less); ludzie są stróżami ich procesu reprodukcji, uniemożliwiają nasionom otwieranie nowych linii stawania się. W efekcie rośliny zostają zanimalizowane - ludzki świat zostaje ustanowiony ich „zewnętrzem”, a zablokowane nasiona stają się ich nowym „wnętrzem" ${ }^{7}$.

\section{Morfogeneza istoty otwartej}

Żeby zmierzyć się ze specyfiką istoty niezwierzęcokształtnej, Pouteau wprowadza (zapożyczoną od Francisa Hallé ${ }^{48}$, który z kolei powołuje się na prace Wolfganga Hagemanna) kategorię ,istot otwartych” (open beings), które tworzą osobne „królestwo”. Ten gest autorka wyjaśnia następująco: biologia — o czym była już mowa - rozpoznaje świat organizmów żywych jako kontinuum, a równocześnie, ze względów historycznych i praktycznych, posługuje się taksonomiczną kategorią królestwa. Królestwo jest — z naukowej perspektywy — bytem nominalnym, potocznie jednak jest traktowane jak byt realny. Wychodząc od potocznego, intuicyjnego i operacyjnego rozumienia inności (królestwa) roślin, łatwiej wskazać różnicę, określić, czym jest rośl-inność (plantness), nie tracąc równocześnie z oczu kontinuum życia w procesie ciągłego stawania się $e^{49}$. Kategoria królestwa jest zatem operacyjnie użyteczna, nie powinna jednak być pojmowana jako desygnat zbioru obiektów (przykładowo: roślin) w przestrzeni, a raczej

\footnotetext{
45 S. Pouteau, Plants..., s. 87.

46 Ibidem, s. 88.

${ }^{47}$ Ibidem, s. 87-91.

${ }^{48}$ F. Hallé, In praise of plants, Portland 2011.

49 Por. S. Pouteau, Beyond...
} 
jako ogół „form w działaniu” 50 , istnień kształtujących się w polu specyficznych sił (takich jak ciśnienie lub grawitacja).

Rośliny należą do królestwa „istot otwartych”. Roślinną otwartość charakteryzuje ciągły wzrost oraz nieskończoność stawania się, rozmywająca krawędzie, destabilizująca kategorie „osobnika, kolonii, społeczności i gatunku” i wytwarzająca nowe kategorie, jak metapopulacja, ,poszerzony osobnik” (wider individual) ${ }^{51}$.

Zarówno Houle, jak i Pouteau śledzą przebieg procesu morfogenezy u roślin naczyniowych. Houle wskazuje, że ciała roślinne i zwierzęce rozwijają się ze sfery (jaja), która jest obiektem absolutnie symetrycznym, centrycznym. Dojrzały embrion rośliny ma dwie spolaryzowane sfery merystemów wierzchołkowych: pędowego (SAM) i korzeniowego (RAM). W toku rozwoju część komórek wędruje w górę, część w dół, równocześnie wydłużając się i tworząc wertykalną oś rośliny (u kręgowców, w tym ludzi, oś ta jest kształtowana przez kręgosłup); pozbawienie komórki ściany i wyizolowanie protoplastu skutkuje regresem do sferyczności. Druga oś kierunkowego rozwoju, oś horyzontalna, jest promienista (radial) - wpływa na okrągłość i rurkowatość ciał. Synchronizacja wzrostu wertykalnego i horyzontalnego następuje zawsze na linii wewnętrzne-zewnętrzne, w polu sił dośrodkowej i odśrodkowej. Inaczej jest w wypadku embrionu zwierzęcego, który przechodzi ważny, niewystępujący u roślin proces różnicowania, gastrulację, w której trakcie tkanki ulegają specyfikacji na warstwy endo-, mezoi ektodermy; celem procesu jest wytworzenie w embrionie wnętrza i zewnętrza ${ }^{52}$.

Pouteau poddaje analizie specyfikę sił, którym podlega organizm w procesie morfogenezy. Zwierzęta rozwijają się w polu sił koncentrycznych, natomiast rośliny - w polu formatywnej siły osiowej (filotaksji spiralnej). Siła osiowa czyni z tych ostatnich istoty otwarte, zawsze niedokończone, bezustannie przekształcające się, natomiast siła koncentryczna - u zwierząt — prowadzi do integracji, zamknięcia procesu $\mathrm{w}$ ostatecznej formie bytu ${ }^{53}$. U roślin lądowych siły działają zwykle wzdłuż osi wertykalnej (1D) - grawitotropizm i fototropizm. Poza tym roślina jest zorganizowana dwuwymiarowo (2D), czyli wytwarza duże powierzchnie przepływu laminarnego z zachowaniem symetrii proksymodystalnej (wzdłuż osi podłużnej, na przykład liści). Dostrzegalny jest także ruch dośrodkowy ujawniający się w postaci spiralnego uporządkowania odrostów wzdłuż łodygi, wytwarzający trójwymiarowe (3D) struktury.

Ponieważ rośliny nie przechodzą w trakcie rozwoju embrionalnego wspomnianego już procesu gastrulacji, nie mają morfologicznie wykształconego wnętrza/ zewnętrza. Wnętrze, zamknięte centrum, skłania do konsumpcji, czyli pochłaniania zewnętrza i katabolizmu (rozkładu i przetwarzania materii). Istoty roślinne są anaboliczne (dążące do nieskończonego wzrostu), nie-topiczne (niemające topo-

\footnotetext{
50 S. Pouteau, Plants..., s. 84.

${ }^{51}$ S. Pouteau, Beyond..., s. 19.

52 K. Houle, Facing...

53 S. Pouteau, Plants..., s. 85 .
} 
su, niezajmujące wyraźnie odgraniczonego miejsca w przestrzeni) oraz nie ego-, ale geo- i heliocentryczne. Istoty wegetalne równocześnie pochłaniają i wytwarzają (odrzucają, oddają fragmenty siebie), tworząc w ten sposób złożone układy relacyjne $\mathrm{z}$ innymi istotami ${ }^{54}$.

Wychodząc od relacyjności (organizmy zawsze już są w relacji), Houle poddaje krytyce ontocentryczny sposób przedstawiania komunikacji roślinnej, charakterystyczny dla biologicznych studiów nad zachowaniem i komunikacją roślin ${ }^{55}$. Zgodnie z tą krytykowaną przez autorkę wykładnią relację przedstawia się jako diadyczną komunikację zapośredniczoną przez substancje chemiczne — roślina (,osobnik") wytwarza specyficzne lotne związki organiczne (VOCs - volatile organic compounds), chemiczny „podpis”, który zmienia się w sytuacji stresu. Jest to reakcja obronna (system immunologiczny w działaniu), rozprzestrzeniająca się od indywidualnej rośliny na zewnątrz, czytelna dla innych osobników roślinnych i nie-roślinnych. Houle uważa jednak, że o ekologicznym kolektywie należy myśleć inaczej i traktować substancje lotne nie jako medium komunikacyjne, ale czynnik sprawczy — dzięki nim rośliny mogą „bywać” w partnerskich relacjach z różnorodnymi organizmami należącymi do królestw roślin, grzybów i zwierząt ${ }^{56}$. Tak rozumiane relacje, oparte na transferach sygnałów „chemicznych, mechanicznych i elektrycznych", zawiązują się nie tylko w medium gazowym (powietrze), lecz także przez podziemne sieci mikoryzalne. Co istotne, nie ma dowodów na to, że relacja ma zawsze na celu korzyść (reprodukcyjną) organizmu — w wymianie często bierze udział wiele stron, których korzyści i straty trudno jednoznacznie zidentyfikować. „Stawanie się rośliny pozwala myśleć o relacjach raczej jako o przejściowych sojuszach niż strategiach" ${ }^{27}$.

\section{Relacyjność, troska i wiedza}

Wychodząc od stwierdzenia, że różne byty zawsze już są w relacji, współtworzą i współdzielą światy, a etyka jest „sposobem życia, sposobem egzystencji”, scenariuszem działań i wyborów tworzonym w czasie rzeczywistym, spotkaniem, egzystencjalnym skrzyżowaniem ${ }^{58}$, a także wpisując swoje rozważania w feministyczno-nowomaterialistyczną, etyczno-onto-epistemologiczną ramę, chciałabym zaproponować myślenie i praktykowanie etyki roślin jako opartej na wiedzy troski o istotę zawsze już uwikłaną (również z nami, ludźmi) w proces relacyjnego współtworzenia światów.

\footnotetext{
54 Por. ibidem.

55 K. Houle, Animal..., s. 98.

56 Ibidem, s. 104.

57 Ibidem, s. 112.

${ }^{58}$ M. Marder, Plant morality..
} 
Relacyjność można rozumieć dwojako: albo jako efekt procesu splatania (się) różnych elementów, albo jako pole sił kształtujące tymczasowe asamblaże. W pierwszym przypadku myślimy o sieci (network), którą tworzą odrębne, zawsze-już-gotowe, ontologicznie stabilne elementy. Przyjmując tę perspektywę, Maria Schörgenhumer argumentuje, że w wypadku relacji ludzi i roślin troska powinna być rozumiana jako praktyka relacyjna, aktywne zaangażowanie: ochrona, pomoc, wsparcie; troska wymaga uwagi i wrażliwości, otwartości, oddania, cierpliwości, skromności, pragnienia dla innej lub innego tego, co najlepsze, gotowości uczenia się oraz podjęcia działania (aktywności) mającego na celu zaspokojenie jej lub jego potrzeb ${ }^{59}$. Równocześnie, biorąc pod uwagę roślinną odmienność, powinniśmy zadać pytanie o to, jak wspólnie możemy kształtować nasz świat-nasze życie (lifeworld) ${ }^{60}$.

W drugim przypadku — relacyjności rozumianej jako pole sił — cechy doraźnie i lokalnie wyłaniających się elementów, bytów, istnień są zmienne i zależne od lokalnych i czasowych powiązań. Pole sił bezustannie przekształca się wraz z fluktuującymi intensywnościami. W wypadku pola sił będziemy mówić raczej o splataniu się (entanglement lub meshwork za Timem Ingoldem) czy wspólnym wyłanianiu się, współstawaniu się, określanym również jako koewolucja czy sympojeza (Haraway).

„Byty konstytuują siebie same oraz siebie nawzajem poprzez »ujęcie« (prehension) czy chwytanie. Byty nie poprzedzają swoich relacji" ${ }^{\prime 61}$. Relacja jest prymarną materią, z której wyłaniają się elementy będące $\mathrm{w}$ relacji - to właśnie Karen Barad określa mianem intra-akcji (intra-action) ${ }^{62}$. Materia nie jest właściwością rzeczy, ale tym, co różnicuje, wytwarza i jest wytwarzane w procesach materialno-dyskursywnych. Barad zwraca uwagę, że ,»[1]udzkie ciała« $\mathrm{i} » l u d z k i e$ podmioty« nie istnieją jako takie uprzednio; nie są też po prostu produktami końcowymi. »Ludzie« nie są ani czystą przyczyną, ani czystym skutkiem, ale stanowią część świata w jego otwartym stawaniu się"63; »[1]udzkie« ciała nie odróżniają się w żaden istotowy sposób od ciał »nie-ludzkich «”, „[c]iała to nie przedmioty wyposażone w naturalne granice i własności; są one materialno-dyskursywnymi fenomenami" 64 — pisze.

Organizmy ludzkie i nie-ludzkie podlegają, jak rzecz ujmuje Myra Hird, „relacyjnej materialności" — ludzie, najmłodsi mieszkańcy Ziemi, nie tworzyli ani

59 Por. M. Schörgenhumer, Caring for plants. Cultivating relational virtues, [w:] Plant Ethics..., s. $110-118$

${ }^{60}$ Por. M. Coeckelbergh, What do we mean by a relational ethics? Growing a relational approach to the moral standing of plants, robots, and other non-humans, [w:] Plant Ethics..., s. 98-109.

${ }^{61}$ D. Haraway, Manifest gatunków stowarzyszonych, [w:] Teorie wywrotowe. Antologia przekładów, red. A. Gajewska, Poznań 2012, s. 245.

${ }^{62} \mathrm{~K}$. Barad, Posthumanistyczna performatywność: Ku zrozumieniu, jak materia zaczyna mieć znaczenie, [w:] Teorie wywrotowe..., s. 326.

${ }^{63}$ Ibidem, s. 348.

${ }^{64}$ Ibidem, s. 351. 
nie wybierali materialnych uwikłań, za które obecnie muszą wziąć odpowiedzialność ${ }^{65}$. Środowiskowa etyka podatności na zranienie (ethics of vulnerability) wymaga uważności na „poszerzonych innych”66, których nie znamy, z którymi często nie mamy bezpośredniej styczności, a których dotykają nasze działania. Wyłaniające się światy, współwytwarzane przez ,heterogeniczne, wzajemnie zależne formy oraz procesy życiowe i materialne" ${ }^{97}$, wymagają specjalnego rodzaju troski. A troska to „etyczno-afektywne codzienne praktyczne działania, które mierzą się z nieuniknionymi problemami istnień współzależnych"68; to ,żywy, afektywny stan, etyczne zobowiązanie oraz praktyczna praca" ${ }^{\prime 9}$ - troska jest zawsze konkretną, ucieleśnioną praktyką.

Thom van Dooren postuluje konieczność zdobywania „kontekstualnej i krytycznej” wiedzy o przedmiocie troski, „wiedzy, która równocześnie każe nam włączyć się w ryzykowna grę (places us at stake in the world) i zmusza do wzięcia odpowiedzialności" ${ }^{\prime 70}$. Gdy przedmiotem naszej troski jest istota roślinna, musimy zaakceptować, że jest ona zupełnie od nas różna. Istota otwarta „nie jest rzeczą, jest procesem. Tym, co egzemplifikuje ciało rośliny, jest bezustanne rozwijanie się, niekończący się strumień życia i ewolucji" ${ }^{71}$. Gilles Deleuze i Felix Guattari dostrzegli tę specyfikę roślinnego stawania się i określili ją zasadą kłącza. Choć autorzy ci proponowali zasadę kłącza raczej jako matrycę ludzkiego filozofowania i bycia, warto odczytać ich wypowiedź bardziej dosłownie. Materialny kłączowy splot (aktualny i wirtualny) łączy roślinę z wieloma organizmami i czynnikami środowiskowymi, umożliwiając jej morfogenezę. Roślina „staje się innym przez entropię, wzrost i metamorfozę" 72 — a więc proces jej rozwoju jest tożsamy z procesem stawania się innym. Stawanie się innym nie opiera się na imitacji, ale generowaniu nowości, „gdy heterogeniczne rzeczy wchodzą w relację", „inwolucyjnie” (czyli wstecznie i pod prąd, niezgodnie z progresywną sukcesją przekształceń) budując alianse ${ }^{73}$.

Etykę roślin — lub raczej etykę ludzko-roślinną (human-plant ethics), jak sugeruje Pouteau ${ }^{74}$ — należy wypracować poza trybami zachodniej maszyny onto-

${ }^{65}$ M. Hird, Waste, landfills, and an environmental ethic of vulnerability, „Ethics and the Environment" 18, 2013, nr 1, s. 107.

${ }^{66}$ Ibidem, s. 115.

${ }^{67}$ M. Puig de la Bellacasa, "Nothing comes without its world”: Thinking with care, „The Sociological Review" 60, 2012, nr 2, s. 198.

68 Ibidem, s. 199.

${ }^{69}$ Ibidem, s. 197.

70 Th. van Dooren, Care, „Environmental Humanities” 5, 2014, s. 293, https://environmentalhumanities.org/arch/vol5/5.18.pdf (dostęp: 3.10.2019).

${ }^{71}$ S. Pouteau, Plants..., s. 91.

${ }^{72}$ H. Stark, Deleuze and critical plant studies, [w:] Deleuze and the Non/Human, red. H. Stark, J. Roffe, Hampshire 2015, s. 185-186.

73 Ibidem, s. 186.

${ }^{74}$ S. Pouteau, Plants..., s. 92. 
logicznej. W miejsce etyki zwierzęcokształtnej (zoomorficznej) Houle proponuje postantropocentryczną (i postzoocentryczną) etykę różnicy, opartą na bliskości i wspólnym stawaniu się. Wychodzi od wspomnianej deleuzeo-guattariańskiej koncepcji stawania się, czyli wchodzenia w relację bliskości, stawania się czymś w polu relacji czegoś z czymś innym, stawania się organizmem molekularnym (a nie molowym, zamkniętym w określonej formie), który - poprzez określoną konfigurację ruchu i spoczynku — nie reprezentuje, lecz wyraża (express) jakość zwierzęcości (animality) lub rośl-inności (plantness) ${ }^{75}$. Houle definiuje stawanie się rośliną jako proces wchodzenia $\mathrm{w}$ relację z tym, co roślinne, tworzenie sojuszu, całości, która „czasownikuje wegetalnie” (verbs vegetally), czyli „wyraża w działaniu unikalne cechy roślin lub żyć roślinnych"76. Poszczególne „stawania się” (becomings) mają tu odmienne „logiki, przejawienia, upojęciowienia, wyobrażenia i wartości (logics, phenomenalities, conceptualities, imaginaries and values) i umożliwiają nam zbliżenie się (,, enter into ” proximity) z wieloma zupełnie innymi myślami i ciałami"77.

Wraz z proliferacją biologicznych badań nad wrażliwością, komunikacją i sposobami życia roślin oraz rozwojem krytycznych studiów nad roślinami i posthumanistyki krytycznej pojawiły się liczne próby formułowania na nowo etyki roślin. Ujęcia formułowane w obrębie filozofii moralnej i etyki środowiskowej często pomijają Inność tych żywych istot i dokonują nieuprawnionej ekstensji rozstrzygnięć wypracowanych w obrębie tradycyjnej (ludzkiej) etyki i etyki zwierząt. Zrozumienie radykalnej wyjątkowości roślinnej morfogenezy pozwala człowiekowi nawiązywać bliskie relacje współstawania się z Innym — istotą roślinną, istotą otwartą. Propozycje problematyzujące specyfikę istot roślinnych (Pouteu, Houle) koncentrują się na morfogenezie, płynnej topologii i otwartości istot roślinnych oraz na relacyjności, pojmowanej jako pole sił umożliwiające kształtowanie wieloczynnikowego i wielogatunkowego organiczno-nieorganicznego milieu. Nie zoomorfizując istnień wegetalnych ani samego systemu pojęciowego, biorą pod uwagę zarówno poszczególne organizmy roślinne wraz z ich czasową i lokalną ekspresją, jak i kolektywne procesy współstawania się.

Proponowana relacyjna etyka troski opartej na wiedzy odrzuca dialektyczną praktykę lokowania rośliny na pozycji nie-zwierzęcia, reinterpretuje kategorie filozoficzne i etyczne w kontekście czasoprzestrzennej specyfiki życia roślinnego i bierze pod uwagę sposób życia organizmu roślinnego w jego środowisku, uwzględniając cielesne i materialne relacje rośliny z innymi organizmami

\footnotetext{
${ }^{75}$ K. Houle, Animal..., s. 97.

76 Ibidem.

77 Ibidem.
} 
oraz jej sympojetyczną ${ }^{78}$ i transkorporealną ${ }^{79}$ plastyczność. Etyko-onto-epistemologia (również ta roślinna)

wyłania się jako ważne ujęcie dynamicznego wytwarzania materii (naszego stawania się w odniesieniu do ontologii) i znaczenia (w odniesieniu do epistemologii), obu już zawsze splecionych z zagadnieniami zobowiązania i odpowiedzialności za relacje w ich ciągłych rekonfigu$\operatorname{racjach}^{80}$.

\section{Plant ethics: Knowledge, care, and co-becomings}

Abstract

The author calls for plant ethics sensitised to vegetal alterity. She outlines the major positions in the field of environmental ethics, whereby she focuses on the calls to go beyond the extensionist framework. She answers questions about how plants emerge in material-discursive processes and how they are inscribed in biopolitical regimes. She introduces the approaches to plantness that reconsider the plant as a processual (Houle) and open (Pouteu) being. The author appeals for developing plant ethics understood as a knowledge-based ethics of care for the Other entangled in multiple material and embodied co-becomings.

Keywords: plants, ethics, biopolitics, becoming, care

\section{Bibliografia}

Alaimo S., Bodily Natures: Science, Environment, and the Material Self, Bloomington 2010.

Attfield R., Forest ethics, [w:] Plant Ethics: Concepts and Applications, red. A. Kallhoff, M. Di Paola, M. Schörgenhumer, Abingdon-Oxon-New York 2018, s. 121-130.

Barad K., Posthumanistyczna performatywność. Ku zrozumieniu, jak materia zaczyna mieć znaczenie, [w:] Teorie wywrotowe: Antologia przektadów, red. A. Gajewska, Poznań 2012, s. 323-360.

Coeckelbergh M., What do we mean by a relational ethics? Growing a relational approach to the moral standing of plants, robots, and other non-humans, [w:] Plant Ethics: Concepts and Applications, red. A. Kallhoff, M. Di Paola, M. Schörgenhumer, Abingdon-Oxon-New York 2018, s. $98-109$.

Dooren T. van, Care, „Environmental Humanities” 5, 2014, s. 291-294, https://environmentalhumanities.org/arch/vol5/5.18.pdf.

ECNH (Federal Ethics Committee on Non-Human Biotechnology), The Dignity of Living Beings with Regard to Plants: Moral Consideration of Plants for Their Own Sake, Berne 2008.

Hallé F., In Praise of Plants, Portland 2011.

78 Por. D. Haraway, Staying with the Trouble: Making Kin in the Chthulucene, Durham 2016.

79 Por. S. Alaimo, Bodily Natures: Science, Environment, and the Material Self, Bloomington 2010.

${ }^{80}$ M. Radomska, Towards a posthuman collective: Ontology, epistemology and ethics, „Praktyka Teoretyczna" 1, 2010, s. 110. 
Haraway D., Manifest gatunków stowarzyszonych, [w:] Teorie wywrotowe. Antologia przekładów, red. A. Gajewska, Poznań 2012, s. 241-260.

Haraway D., Staying with the Trouble: Making Kin in the Chthulucene, Durham 2016.

Hird M., Waste, landfills, and an environmental ethic of vulnerability, „Ethics and The Environment" 18, 2013, nr 1, s. 105-124.

Houle K., Animal, vegetable, mineral: Ethics as extension or becoming? The case of becoming-plant, ,Journal for Critical Animal Studies” 9, 2011, nr 1-2, s. 93.

Houle K., Facing only outwards? Plant bodily morphogenesis and ethical conceptual genesis, [w:] Plant Ethics: Concepts and Applications, red. A. Kallhoff, M. Di Paola, M. Schörgenhumer, Abingdon-Oxon-New York 2018, s. 70-81.

Kallhoff A., Plants in ethics: Why flourishing deserves moral respect, „Environmental Values” 23, 2014, nr 6, s. 685-700.

Kallhoff A., The flourishing of plants: A neo-Aristotelian approach to plant ethics, [w:] Plant Ethics: Concepts and Applications, red. A. Kallhoff, M. Di Paola, M. Schörgenhumer, Abingdon-Oxon-New York 2018, s. 51-58.

Kallhoff A., Di Paola M., Schörgenhumer M., Introduction, [w:] Plant Ethics: Concepts and Applications, red. A. Kallhoff, M. Di Paola, M. Schörgenhumer, Abingdon-Oxon-New York 2018, s. $1-9$.

Marder M., Plant-Thinking: A Philosophy of Vegetal Life, New York 2013.

Marder M., Plant morality vs plant ethics, 2016, https://philosoplant.lareviewofbooks.org/?p=177.

Nealon J.T., Plant Theory: Biopower and Vegetable Life, Stanford, CA 2016.

Odparlik S., The dignity of plants. An overview of the discussion in German-speaking countries, [w:] Plant Ethics: Concepts and Applications, red. A. Kallhoff, M. Di Paola, M. Schörgenhumer, Abingdon-Oxon-New York 2018, s. 59-69.

Pellegrino G., The value of plants. On the axiologies of plants, [w:] Plant Ethics: Concepts and Applications, red. A. Kallhoff, M. Di Paola, M. Schörgenhumer, Abingdon-Oxon-New York 2018, s. 13-29.

Petrič Š., Confronting Vegetal Otherness: Strange Encounters, https://www.spelapetric.org/strange-encounters/.

Pouteau S., Beyond "second animals”: Making sense of plant ethics, „,ournal of Agricultural and Environmental Ethics" 27, 2014, nr 1, s. 1-25.

Pouteau S., Plants as open beings: From aesthetics to plant-human ethics, [w:] Plant Ethics: Concepts and Applications, red. A. Kallhoff, M. Di Paola, M. Schörgenhumer, Abingdon-Oxon-New York 2018, s. 82-97.

Puig de la Bellacasa M., "Nothing comes without its world”: Thinking with care, „The Sociological Review" 60, 2012, nr 2, s. 197-216.

Radomska M., Towards a posthuman collective: Ontology, epistemology and ethics, „Praktyka Teoretyczna" 1, 2010, s. 94-115.

Ryan J.Ch., On the death of plants: John Kinsella's radical pastoralism and the weight of botanical melancholia, „Ecozona” 7, 2016, nr 2, s. 113-133.

Sandler R., Is considering the interests of plants absurd?, [w:] Plant Ethics: Concepts and Applications, red. A. Kallhoff, M. Di Paola, M. Schörgenhumer, Abingdon-Oxon-New York 2018, s. $40-50$.

Schörgenhumer M., Caring for plants. Cultivating relational virtues, [w:] Plant Ethics: Concepts and Applications, red. A. Kallhoff, M. Di Paola, M. Schörgenhumer, Abingdon-Oxon-New York 2018, s. 110-118.

Stark H., Deleuze and critical plant studies, [w:] Deleuze and the Non/Human, red. H. Stark, J. Roffe, Hampshire 2015, s. 180-196.

Višak T., Utylitarian plant ethics, [w:] Plant Ethics: Concepts and Applications, red. A. Kallhoff, M. Di Paola, M. Schörgenhumer, Abingdon-Oxon-New York 2018, s. 30-39.

Prace Kulturoznawcze 24, nr 3, 2020

(C) for this edition by CNS 
Zamorska M., Kain, plantacjocen i wykluczanie światów roślinnych, „Kultura - Historia - Globalizacja" 26, 2019, s. 185-195, http://www.khg.uni.wroc.pl/index.php?type=artykul\&id=489 \&lang=en.

Magdalena Zamorska — adiunktka w Instytucie Kulturoznawstwa Uniwersytetu Wrocławskiego, członkini Laboratorium Humanistyki Współczesnej UWr. Interesuje się strategiami twórczymi w obrębie nowej choreografii, a także zagadnieniami z obszaru humanistyki środowiskowej, krytycznych studiów nad roślinami, studiów międzygatunkowych oraz posthumanistyki krytycznej. Autorka książki Obecni ciałem. Warsztat polskich tancerzy butō (2014). Kierowała projektami badawczymi z obszaru tańca i choreografii (Instytutu Muzyki i Tańca, WNHiP UWr), badaczka w projekcie Fundacji om „Neurofizjologia artysty w performance. e.1/2015-2017”. Kuratorka cyklu rezydencji choreograficznych DyFuzje w BWA Awangarda we Wrocławiu (kwiecień-maj 2019 roku). Prowadzi bloga poświęconego współczesnym praktykom ruchowym (choreobiota.pl).

magdalena.zamorska2@uwr.edu.pl 